\title{
CASTE AND ORGANIZATION STUDIES: OUR SILENCE MAKES US COMPLICIT
}

\author{
Snehanjali Chrispal \\ Faculty of Business and Economics \\ The University of Melbourne, Victoria 3010 Australia \\ E-mail: snehanjali.ashish@unimelb.edu.au \\ Hari Bapuji \\ Faculty of Business and Economics \\ The University of Melbourne, Victoria 3010 Australia \\ E-mail: hari.bapuji@unimelb.edu.au \\ Phone: +61-3-8344-9867
}

\author{
Charlene Zietsma \\ Associate Professor, John and Becky Surma Dean's Research Fellow \\ Smeal College of Business, The Pennsylvania State University \\ University Park, PA 16802 \\ Email: cuz147@psu.edu \\ Phone: $+1-814-865-2643$
}

Acknowledgements

The authors would like to thank the editor, Trish Reay and three anonymous reviewers for their critical and constructive guidance in improving this manuscript through multiple revisions.

Citation:

Chrispal, S., Bapuji, H., \& Zietsma, C. (2020). Caste and organization studies: Our silence makes us complicit. Organization Studies. https://doi.org/10.1177/0170840620964038

Date: September 20, 2020 


\title{
Caste and Organization Studies: Our Silence Makes us Complicit
}

\begin{abstract}
The caste system has received scant attention in organization studies, despite persisting over thousands of years, influencing the socioeconomic lives of over a billion people around the world and subjecting over 300 million people to severe socioeconomic discrimination. By overlooking caste, scholars risk conforming subaltern empirics to imperialist knowledge and miss the nuance and complexity that caste can bring to organization studies. We argue that the caste system is an institution that affects the workplace, yet it is difficult to dismantle because of its rooting in bodies and the sacred, which strips away agency. As an institution that is deeply embodied, caste has implications for institutional work, precarious work, and modern slavery. We conclude with a call for scholarly engagement with caste to study its implications in the pursuit of grand challenges and inclusive organizations.
\end{abstract}

Keywords: Caste system, Diversity, Grand challenges, Inequality, Institutions, Precarious work, Modern slavery 
“"'Take that! Tell everyone we scalped you" remembers a Dalit man who went to ask uppercaste landlords for $\$ 80$ of wages they owed his son for work on the farms, but instead, he was scalped by them"

- Gettleman \& Raj, 2018

"During the 17 years Tambe has worked as a waste collector, he has seen his colleagues develop skin, respiratory, and eye ailments; a few have lost fingers to acute infections"

- Changoiwala, 2020

Occurring largely outside the gaze of organizational scholars, the horrific experiences in the epigraphs above show the many indignities inflicted upon the lower castes in their work and social lives. Even mundane acts like sporting a moustache, wearing a gold chain, attending a community festival or applying for a mining license by the lower castes are 'transgressions' subject to violent reprisals (Parikh, Sute \& Olwe, 2018). Caste-based discrimination includes the practice of untouchability by over a quarter of the population in India (Thorat \& Joshi, 2015), and restrictions on access to rental housing (Thorat, Banerjee, Mishra \& Rizvi, 2015), job markets (Siddique, 2011), and even relief after disasters (Aldrich, 2010).

The scale of caste-based discrimination is substantial. It has persisted in India despite unprecedented economic growth and modernization. ${ }^{1}$ Its prevalence also extends beyond India's borders, particularly in South Asia, and with migration, to countries like the U.K. and U.S. (Metcalf and Rolfe, 2010), Kuwait and U.A.E. (Leonard, 2005), Malaysia (Lee \& Rajoo, 1987), and the Caribbean (Roopnarine, 2003). A study in the U.S. found that two thirds of Dalit ("untouchables" in the caste system) workers in the U.S. said they were treated unfairly at work (Zwick-Maitreyi, Soundararajan, Dar, Bheel \& Balakrishnan, 2018). For example, a lawsuit

\footnotetext{
${ }^{1}$ The poverty rate in India declined from 21.6 percent to 13.4 percent between 2011/12 and 2015 (World Bank, 2019) and 271 million Indians were lifted from multidimensional poverty between 2006 and 2016 (UNDP, 2019) 
brought against Cisco by California state authorities in 2020 alleged that Cisco failed to take corrective action when a lower caste engineer was discriminated against in pay, in work assignments, and socially by his higher caste colleagues (Dutt, 2020).

In this essay, we argue that caste is not only a social evil, but it is also a deeply-rooted, embodied and sacred institution that influences organizations and the workplace around the world. Yet, the field of organizational studies has paid scant attention to the caste system, despite having a long and vibrant research tradition on discrimination rooted in demographic characteristics, such as gender, race and class (Amis, Mair \& Munir, 2020), and a growing body of research on the Indian subcontinent and its diaspora. We argue that when we, as organizational scholars, ignore caste we are complicit in the dehumanizing and disappearing of hundreds of millions of lower caste people around the world. This raises the question: is management research on people of the Indian subcontinent truly representative of, and more importantly generalizable, to its populations if a deep-rooted institution like caste is not taken into account? Are we perpetrating 'epistemic violence' on those marginalized by caste (Spivak, 1988:78)? And is our silence on caste indicative of a larger problem in organization studies of looking the other way to avoid uncomfortable truths?

In the remainder of this essay, we argue that the caste system is an institution that affects workplaces and that a caste lens can problematize existing theories within the field of organization studies, which we illustrate with institutional theory. We also argue that capitalism has leaned into caste, since caste's embodied identities furnish a population that is ripe for exploitation through precarity, workplace abuses and modern slavery. We conclude by calling on organizational scholars to engage with caste to tackle grand challenges.

\section{Why has caste been neglected in organizational research?}

We argue that caste has been neglected in organizational research for at least three reasons. First, an overwhelming majority of scholars from India are high caste, and thus enjoy 
caste privileges. For example, across 13 Indian Institutes of Management, 620 out of 642 (96.5\%) faculty members belonged to the upper/forward castes whose population share is less than 30\% (Joshi \& Malghan, 2018). The profile of Indian diaspora scholars is likely similar given that 90 per cent of the people in the U.S. of Indian origin are from the upper castes (Kapur, 2010). Scholars from the upper castes may dismiss the importance of caste because they do not notice its effects or because it throws a shadow on the legitimacy of their own achievements. Perhaps as a result of an unbalanced exposure to upper-caste beliefs and perspectives, the global North has somewhat uncritically embraced caste-reinforcing aspects of Indian culture, including the concept of karma and Indian festivals, and the political philosophy of Gandhi, who largely supported the caste system.

Second, caste may be unseen or ignored due to knowledge taboos (Hudson, Okhuysen \& Creed, 2015) and elite and Western hegemonies, which often exclude knowledge systems of historically disparaged groups (Chilisa, 2012). The caste-privileged may feel uneasy about exposing caste as a cultural taboo, and the caste-disadvantaged may feel emotional turmoil because doing caste-focused research may require them to relive and shine a light on their own suffering, and it may be dismissed as activism rather than research, and thus inappropriate for a scholar (Hudson et al., 2015).

Third, when scholars have addressed caste, they tend to treat it like race and class, ignoring their differences (Jal, 2018). While both race (Wiegman, 1995) and caste are embodied, caste is rooted in religious ideologies, providing sacred justification for seeing lower caste members as "other", "less than" and even "untouchable" objects of disgust. While class and caste both feature social hierarchies, class is rooted in material resources (income, education, and occupational prestige) (Côté, 2011), and thus class mobility may be achieved through individual pursuit, even if it is difficult. Caste, on the other hand, is perennial and social mobility is restricted, even when economic mobility is achieved. 


\section{Caste as an Institution that Affects Workplaces}

The caste system draws its legitimacy from religious scriptures and affects individuals' social position, occupational choices, social interactions, cultural practices, and organizational life (Bapuji \& Chrispal, 2020). The origins of the caste system can be traced to Hindu religious scriptures that suggest that the God of creation, Brahma, created four types of people from his body in the following order: Brahmins from his head, Kshatriyas from his arms, Vysyas from his thighs, and Sudras from his feet (Deshpande, 2010). These people were segregated and perceived hierarchically with Brahmins at the top followed by Kshatriyas, Vysyas, and Sudras. Additionally, a fifth group that can be either seen to be outside the caste system or below the Sudras consisted of the Dalits or untouchables who were considered impure and 'polluted' (Grey, 2005) and the Adivasis, or indigenous tribals. Each of these five categories also encompasses thousands of sub-castes.

The caste system places individuals in immobile positions in a social hierarchy and has also traditionally predicated the occupations of individuals: Brahmins were priests, advisors, and scholars; Kshatriyas were rulers, soldiers, and administrators; Vysyas were traders and merchants. On the other hand, Sudras were laborers, artisans, and servants. As Dalits and Adivasis were outside of the caste system, they were assigned menial jobs and mostly ended up foraging and scavenging (Desai \& Dubey, 2012). Through thousands of years of practicing it, the effect of caste on occupations can be seen today in organizations, with certain professions predominantly practiced by certain castes. Brahmins predominate in knowledge-based professions like the STEM occupations, such that some of the premier science and technology institutes are derisively referred to as Iyer Iyengar Institutes (Iyer and Iyengar are two prominent Brahmin last names in South India; Thomas, 2020). In contrast, lower castes predominate in menial, hazardous and 'unskilled' work (Varman \& Chakrabarti, 2004). 
The caste hierarchy not only assigns status, but also purity to castes with Brahmins considered the purest. The ritualistic purity is preserved and normalized through endogamy (marriage within caste) and segregated housing, as well as an array of social interactions, rituals, and behaviours, including diet (Chakravarti, 2012). Organizational systems and practices also reinforce this ritualistic purity between castes. For instance, some organizations set up separate entrances and wash basins for vegetarians and 'non-vegetarians' (e.g., Indian Institute of Technology Chennai), while others (e.g., Indian Institute of Science Bangalore) dedicated a cafeteria to serve only vegetarian food, which came to be seen as an exclusive dining area for Brahmins, even though other cafeterias served both vegetarian and 'nonvegetarian' food (Thomas, 2020). Notably, individuals from lower castes often adopt vegetarianism after being promoted to managerial positions (Mahadevan, 2015).

Organizations use ceremonies "as a condensed dramatic form of the culture" (Dandridge, 1986:164). Workplaces, such as the Indian Institute of Science, organize the Ayudha Puja a ceremony conducted by a Brahmin priest to worship weapons, now extended to tools and machines in general. Such ceremonies normalize Brahminical ideologies within the realm of science and reveal the "discursive transformation of Brahminical Hinduism into a culture at the institute (and likely in Indian science more generally)" (Thomas \& Geraci, 2018:115-116). Many lower caste and female employees (whose access to weapons/tools was historically restricted), as well as non-Hindu employees, are expected to join the ceremony because it is seen as a cultural practice. These rituals form the crux for powerful actors to exert and legitimize their authority using symbolic means, thus, endorsing their 'ideological positions' and exploiting existing social conditions (Dacin, Munir \& Tracey, 2010:1396).

Although caste permeates socioeconomic lives in many ways, some scholars have not considered caste even when the context makes it necessary, thus losing nuance and opportunities for new insights. We illustrate this using a study of the success of US motels 
owned by immigrant Gujarati entrepreneurs by Kalnins and Chung (2006). They found that the likelihood of survival of an immigrant entrepreneur's hotel increases when it is surrounded by branded hotels owned by individuals from their ethnic group, since immigrants can acquire resources from their fellow immigrants. The authors do not use the word caste in the paper, although they note that over $90 \%$ of Gujarati hotels are owned by those with the surnames Patel and Bhakta. It is no coincidence that these surnames belong to the Vysya category whose ordained occupations were trade and commerce, allowing them to accumulate and access the necessary resources and opportunities (Bapuji \& Chrispal, 2020). In other words, what has been captured as 'immigrant group membership' by Kalnins and Chung (2006) is actually 'caste membership'. By recognizing this, the study could have conducted a more nuanced examination of hotel survival by caste rather than by ethnic group. Adopting a caste lens would have also shed light on caste as an antecedent of social capital, with implications for individuals and organizations. Through shared genealogy and intermarriage, caste membership serves as social capital among members of the same caste, thus facilitating transactions. Contrarily, the lack of shared caste membership hinders relationships and may explain why over $90 \%$ owners are Patel and Bakta, and not others. In short, not only can caste afford new insights, but can also challenge theories of organization studies, as we illustrate next with institutional theory.

\section{Why is it so Hard? Caste as a Different Kind of Institution}

In this section, we argue that trying to fit caste into existing institutional conceptual moulds may be erroneous because caste is an ambiguous institution. This ambiguity is fortified because caste is embodied and connected with the sacred. As such, it is experienced and justified both viscerally and morally, with strong emotions associated with its violation. These factors strip away agency from some actors and bestow agency on others.

We explicitly reject the folk sociology of "essentialism", which attributes a social group, i.e., race, gender or caste, to particular identities that are immutable, and 'naturalizes' 
enduring power relations among diverse social groups (Mahalingam, 2007). Under essentialism, a lower caste Sudra is a lesser person, an Adivasi is uncivilized, and a Dalit is an 'untouchable' because it is in their nature, they are in 'essence' polluted, and it is natural that Brahmins are more 'pure and scholarly' than the rest. The essentialist view is largely taken for granted by those who practice caste, and it is inimical to remedying the inequalities that stem from it (Prasad, 2012). It ignores how caste, like gender, operates as a socially constructed multidimensional institution (McCarthy \& Moon, 2018). But, what kind of institution caste may be, may in itself pose a challenge to institutional literature.

Caste is extremely resilient, despite formal restrictions against its use. While attempting to categorize caste as an institution, we considered the notion of a guarded institution - one that is morally accepted and inviolable, and whose practices are vigorously defended by powerful elites (Claus \& Tracey, 2019). Caste, however, does not have explicit political or social legitimacy, nor are elites overtly protecting it. Yet, it is maintained by the practices that reproduce caste without openly legitimizing caste itself, e.g., endogamy through arranged marriages; restricting priesthood to Brahmin men; last names that denote caste; and the everyday mundanity of touch and gaze, voice and silence. Further, caste is maintained by subverting affirmative action and denigrating its beneficiaries as unworthy (Prasad, O'Brien \& Sockbeson, 2020). So, while caste may fit certain criteria of a guarded institution, the fit is imperfect.

Like the total institutions (prisons and asylums) described by Goffman (1961), caste dehumanizes Dalits by ascribing to them an identity of the 'untouchable'. They are forced to live at the peripheries and in ghettos, while performing 'dirty work' - cleaning the environment that they are allowed to enter only to clean. And while inmates like the formerly incarcerated people studied by Toubiana (2019) become acculturated to the identity of an "inmate" by the total institution and stripped of their personal identity, people are born into their caste identity. 
It is in their skin, their name, their relationships, their work and their habits, and it is reinforced by others constantly in social interactions. It seamlessly gets carried to non-caste contexts, such as the global North, particularly for the 'untouchables', who are stigmatized, since "embodied identities are trans-situational" (Heise \& MacKinnon, 2010: 3; Stryker \& Serpe, 1994). As Heise and MacKinnon (2010: 6) noted: "hierarchies of identities determine to some extent the kind of person an individual can become, and pre-determine life-course trajectories".

Caste problematizes institutional theory because it is not clear what kind of institution it is, though it clearly has strong effects. We argue that the strength of caste as an institution is intimately tied to embodiment, sacredness and the resultant power-structuring visceral/emotional reactions - characteristics which are not well understood by predominantly cognitivist versions of institutionalism, as we discuss below.

\section{Embodiment: To be touchable and untouchable through Caste}

In De anima, Aristotle argues that touch goes beyond the skin, it resides inside the flesh, yet cannot be experienced without the flesh (Shields, 2016). Merleau-Ponty, through his analysis of flesh, demonstrates that the body is both the subject and the object - 'the perceiver and perceived' (Leder, 1990:64). Touch “evokes at once agency and receptivity, authority, and reciprocity, pleasure and pain, sensual indulgence and epistemological certainty" (Harvey, 2003:2). So, what is "untouchable" then? Western philosophers still privilege the individual with agency - having choices about touch (Guru \& Sarukkai, 2018). Moreover, they do not attend to untouchability as 'objects of non-touch' (Sarukkai, 2009). Caste problematizes these views of touch by prescribing who can or cannot touch whom, what, and how.

Within the caste system, one has to continuously be reflective of every act of touching - it is no longer an 'automatic' sense like hearing or seeing (Sarrukai, 2009:44). The influence of untouchability is upon both the Brahmin and Dalit, yet, they experience it differently. For instance, a Brahmin (or any other caste ranked higher) can emit power, revulsion and 
denunciation by withholding touch, while the Dalit faces humiliation and shame based on the Brahmin's actions (Sarukkai, 2009). On both sides, the reactions are visceral, evoking intense emotions, because of the embodied nature of untouchability. What makes the embodiment of untouchability even more severe is the 'sacredness' and the religiosity which underpins it.

\section{The 'Sacred' - At the intersection of gender and caste}

There is a duality in sacredness, that which is 'the impure and taboo' and that which is 'pure and moral' (Hertz, 1973). The sacred is 'embodied in certain objects' - in the 'touchables' as 'pure' and 'untouchables' as 'impure'. The sacred is experienced in and through these objects (Bataille, 1986; Russell, 2017). The 'impure or purity' aspect of the sacred is not experienced by 'the body' in isolation but is conditioned by the culture within which it is situated; 'they are so engrained in the self they can be felt viscerally' (Russell, 2017:168). It is, therefore, essential to understand the body and the social conditions within which it exists, to truly understand the embodied agency at work.

While this visceral embodiment is associated with caste for all, to truly exemplify its effects, we look at the intersection of gender and caste, focusing on the lives of the Devadasis (i.e., servants of the god). At a very young age, girls (primarily from the Dalit communities) are 'married to a goddess' and are not allowed to have an 'earthly marriage'. Historically, they performed artistic forms of dance and song in the temples or for the wealthy and would earn gold or land for the temples. However, in recent times, Devadasis have become forced prostitutes. Lower caste parents relieve their financial burdens by selling their daughters to the temples. As 'sacred prostitutes' in 'ritual sexual slavery' (Parrot \& Cummings, 2008), they perform sexual acts for upper caste men under the guise of religious devotion, justifying everyday violence in a way that other forms of stigmatization and discrimination do not.

The body of a Devadasi is controlled by upper caste men - she has no control over what is done to her body. She has essentially become a dehumanized object with no inherent value. 
Through marriage to the goddess, these girls may enter temples - the domain of 'pure and moral' within the 'sacred', leaving behind the 'taboo' of untouchability. However, when their bodies are used by upper-caste men, they become 'polluted' once again, due to the taboo attached to prostitution. They become touchable only through 'flesh' yet retain their untouchability; the upper caste man can touch her body but won't drink of the same cup (Parrot \& Cummings, 2008). These women internalize 'impurity' and 'pollution' by selling their bodies, but also by being an untouchable, and this embodied impurity can never be thrown off. Those Devadasis who try to escape this stigma, through marriage or giving birth, are unable to because they are stigmatized both as a 'prostitute' and as an 'untouchable'. In contrast, the upper-caste men are not tainted by this impurity or are able to rid themselves of this 'dirt' and shame. Because caste is anchored in sacred doctrines, it makes it difficult to change. Any attempts to change are met with vitriolic opposition through moral outrage and the acquiescence created by systemic power.

\section{Caste, Agency and Institutional Work}

Caste strips away the agency required to resist caste in two ways: through the internal embodiment of systemic power structures (Lukes, 2005) through hierarchical identities and through external repression of agency. This makes institutional work to resist caste both less likely to happen and less likely to be effective.

The internal embodiment of systemic power structures. As mentioned, embodied identities like caste are extremely durable across situations (Heise \& MacKinnon, 2010). Caste is in one's name, one's rituals, one's relations, one's identity, and one's skin - it is a deeper form of institution because one cannot throw it off by any of the usual means of disembedding. The systemic structures of power associated with caste are normalized by repeated enactment (Lukes, 2005). The practices of caste are dehumanizing, involving humiliation, insults, violence and deprivation, akin to those used by Nazis in concentration camps, which aimed at 
"shattering human beings' capacity to act, thus transforming their existence into that experienced by animals" (Marti \& Fernandez, 2013: 1196). Yet those who the Nazis oppressed in concentration camps had previously had other (non-oppressed) lives and other identities. By contrast, lower caste individuals have held that identity from birth, reinforced in everyday life, and they may not even be able to imagine another way.

Power takes on a sinister form when individuals are not aware of their own 'grievances', because their thoughts are so deeply patterned by their embeddedness within an existing order. They see their domination as natural, unalterable, or 'divinely ordained' (Lukes, 2005:28), especially when justified by the sacred. The embodied identities of the lower castes may prevent them from seeing the possibility of and engaging in institutional work. It is like gender, in that it is embodied, and in many religions, gender also features severe taboos around women and what they can do and be, and because the basis is sacred, religious women often follow strict codes of conduct, and impose them on other women, becoming their own worst oppressors (George, 2008). Yet for women of higher castes, there may still be access to power and status through their position next to their powerful men. But for women and men of lower castes, that is not the case, as they can never (literally) stand next to the powerful.

The external repression of agency. If institutional work does emerge, like the mundane micro-emancipatory acts of rebellion of the powerless (Prasad \& Prasad, 2000) such as sporting a moustache, asking for wages due, or requesting protective gear to work in sewers, it often evokes a violent reaction that seems disproportionate to the transgression. Because caste is situated in the sacred (religious) tenets, its transgression stimulates moral outrage (Tetlock, Kristel, Elson, Green, \& Lerner, 2000), a 'cognitive, affective and behavioural' response to the transgression of sacred values. Violators of sacred norms are met with anger, contempt, ostracism and violence, as the examples we outlined in the introduction show. In another example, in 1990, when the government decided to create a 27 per cent quota in central 
government jobs to provide equal opportunities for the historically marginalized Other Backward Castes, upper castes responded violently, destroying public property and attempting self-immolation (Mandal, 2019). Moreover, when people within a community have vested interests in existing sacred values are asked to trade them for those that are secular - a 'taboo trade-off', they become obstinate, insensitive and apathetic (Tetlock, 2003). Thus, institutional work is both unlikely to happen and unlikely to be successful with respect to caste.

When institutional work to affect caste has been undertaken, it is often through the agency of those in higher power positions (Marti \& Mair, 2009; Mair, Wolf \& Seelos, 2016). For example, Sulabh International (a non-profit organization that operates public toilets in India with a staff of 35,000, predominantly Dalits) has gained acceptance and acclaim although sanitation work and Dalit people are stigmatized; however, the founder is a Brahmin. It begs the question: would it have gained momentum, been accepted or had resources, if the founders were Dalits or other lower castes? This is underscored by the finding that the participation of lower caste farmers in developmental programs is largely contingent on the performance of boundary work by the upper caste volunteers (Qureshi, Sutter \& Bhatt, 2018). In short, caste challenges our notions of what constitutes institutional work and who can truly perform it.

\section{Implications of Caste}

As discussed in the previous section, caste problematizes our generally cognitive understanding of institutions by operating at a more visceral, embodied, and sacred level, which strips away the agency of the lower castes. This has numerous implications for our theories of organization studies that revolve around individuals, workplaces, and institutions. We illustrate it by discussing the implications of caste for precarious work, and modern slavery.

\section{The Precarious Work of the 'Untouchable'}

The embodiment of 'untouchability' through caste has implications for affected people's 'humanness' but also for the occupations they are subjected to. There is naivete in 
assuming that function is an antecedent to untouchability - a misconception that one cannot touch another because they engage in 'polluted' jobs of manual scavenging or cleaning human excretion (Sarrukai, 2009). Untouchability manifests because one is minimized to the 'flesh' and dehumanized, and forced to clean carcasses and faeces. Caste, through untouchability, makes the lives of the lower-castes precarious and makes them engage in 'precarious work'. Precariousness, as Butler (2004) argues, is a condition that subjects some lives to being meaningless and 'not mattering'. As untouchables, 'they' are deprived of material and social needs and conditions that make life liveable; their lives become unworthy of grievability (Butler, 2009), both by themselves and others.

Because of their position in the caste hierarchy, and being seen as 'polluted' bodies, the work they adopt is also 'precarious' - jobs that are 'risky and uncertain' (Kalleberg \& Vallas, 2018). Precarious work is the "combined experience of insecurity (of position, entitlements, and livelihood), of uncertainty (as to their continuation and future stability) and of unsafety (of one's body, one's self, and their extensions: possessions, neighborhood, community)" (Bauman 2000:160-161). COVID-19 heightened this precarity for the Dalits. Unlike most Indians, who were confined to their homes, sanitation workers, primarily Dalits, were employed to sanitize and clean waste. Yet, they were treated as commodities and not given even the basic safety equipment needed. They 'took' great risks of contracting the coronavirus, not only by picking up medical waste and garbage that contained syringes, masks and gloves, but also by coming into contact with human waste (Changoiwala, 2020).

Precarious work engenders a 'mode of domination of a new kind' (Bourdieu, 1998:85). For Butler (2015:vi), precarity "has itself become a regime, a hegemonic mode of being governed, and governing ourselves". This precarity is a result of agendas directed to the formation of hegemony of the capitalist elites. Capitalism, through active and aggressive restructuring and exploitation of social arrangements, pushes its hegemonic dogmas into social 
life (Green, 1993), thus further enabling the conversion of humans into commodities and stripping away autonomy and agency from them. In short, attention to caste, with its inherent dehumanizing and othering, challenges and extends our notions of who does precarious work, who gets it done, and why it becomes acceptable.

With zero-hour contracts, the effacement of ride-hailing drivers as "worker-bots" that are dehumanized parts of organizational technology (Roberts \& Zietsma, 2018), and the increasing trend of turning frontline service workers of many types into faceless, perfectly substitutable labor inputs, precarity in society is extending. As we have seen with the COVID19 pandemic, these "essential workers" are disproportionately Black or minority workers, disproportionately subject to death and disease and frequently subject to insults and violence as they attempt to enforce the use of masks (Bapuji, Patel, Ertug \& Allen, 2020). Attention to caste can help organizational scholars confront the terrible effects of dehumanization and recognize its broader application in precarious work.

\section{Modern Slavery}

A noxious combination of capitalist hegemony and caste creates a 'false consciousness' (Pines, 1954) and conceals the exploitation of 'bodies.' Again, it limits these bodies to commoditized and dehumanized 'flesh'. As Marx (1967) argues, an object that transitions from an uncommodified body to a commodity is deficient of any social relation between people, but stands only in relation to other products, participating in the market (Andreescu, 2018). Capitalist markets obscure exploitation because they see bodies as commodified components of production, rather than having inherent value; they are devoid of 'humanness' - a 'fetishism of commodities' (Marx, 1967: 73; Andreescu, 2018). In other words, modern slavery is not only a result of exploitative class relations, but also results from dehumanizing caste relations.

The forms of exploitation and slavery arising from caste are absent from conceptions of modern slavery. The label of 'modern slavery' itself is problematic because it tries to 
understand exploitation from a Western lens and thus suppresses the unique form of oppression associated with caste. By focusing on the 'modern', it renders the historic and ancient forms of slavery absent, oblivious to their durability. By using the slavery lens, the focus narrows to economic oppression (i.e., wages and working conditions) but overlooks the social oppression (e.g., bullying, undermining, and discrimination) that occurs in the workplace (e.g., supply chains) and outside, and the dehumanization that underpins and enables it.

'Modern slavery' has been brought to the fore through its inclusion in the UN Sustainable Development Goals and recognition as a grand challenge. Yet, how it manifests in developing countries and what needs to be combated is still ambiguous (Cruz, O'Connell Davidson \& Sanchez Taylor, 2015). Caste is absent from the literature on modern slavery or is presented as a piece of incidental information. For example, Crane (2013) recognizes that an estimated $80 \%$ of India's bonded laborers are Dalits or Adivasis but does not delve into it and subsumes it under the cultural context. Neither has the subsequent literature on modern slavery, as revealed by a review of modern slavery research that did not even have the word caste in its full text (Caruana, Crane, Gold \& LeBaron, 2020). Similarly, Kara (2019) notes that over 99\% of women workers in the garment supply chains, often subject to horrific workplace abuses, were either Dalits or Muslims. Yet, the focus of his study remains on gender rather than caste. Capitalism leans into caste as a supportive, dehumanizing institution that enables the exploitation of commodified bodies.

In sum, caste problematizes our understanding of institutions because it is a more visceral, embodied institution, underpinned by sacred justifications, which strips away individual agency and humanity in low caste identities which cannot be cast off. This reduces the bodies of lower caste individuals, particularly Dalits, to commodities that can be used in workplaces and society to perform the work of slaves, depriving them of any possibility of engaging in institutional work to disrupt and change their circumstance. Thus, a refusal to 
recognize caste makes scholars of organization studies unknowingly complicit in normalizing and reinforcing the caste system, even while addressing grand challenges in earnest. Further, by failing to recognize the dehumanizing associated with caste, and by turning our gaze away from the least powerful members of society, we run the risk of extending dehumanization through capitalist hegemony to a broader group of humans around the globe.

\section{Removing the Rose-Coloured Glasses - Attending to Caste}

Management research has recently begun to focus on grand challenges with a view to coherently identify and possibly remove pivotal impediments to human development (George, Howard-Grenville, Joshi \& Tihanyi, 2016). In particular, management research has examined grand challenges like climate change, poverty, economic inequality, modern slavery and gender inequality. However, none of these issues can be fully understood without attending to caste, at least in the Indian subcontinent and its diaspora spread around the world. In attending to caste, it is important to remember that a significant distortion occurs when first-world scholars use third-world elites as native informants to represent the voices of the 'Other' (Spivak, 1988), as research that does not attend to caste is likely to do. To correct it, scholars need to prevent unintentionally "appropriating the voice of the subaltern" (Srinivas, 2013:1658), and recognize "the aporetic condition of the subaltern's silence" to engage in relentless pursuits of the 'Other's' truth (Prakash, 1994: 1488).

More broadly, sustainable development goals (with which the grand challenges align closely) such as clean water and sanitation, inclusive industrialization, zero hunger, good health, decent work and quality education cannot be achieved without understanding how caste is deeply intertwined with occupations and access to water, nutritious foods, adequate shelter, health, education, employment and entrepreneurship (Bapuji \& Chrispal, 2020; Saracini \& Shanmugavelan, 2019). Further, attention to caste reveals the most pernicious effects of unrestrained capitalism in its tendency to dehumanize and exploit those with the least power. 
In short, attention to caste calls into question how organizational scholars understand and address societal problems, including those as complex as grand challenges.

Research on grand challenges has noted that organizational practices produce unequal organizations and societies (Bapuji et al., 2020a). This research has predominantly focused on the reproduction of gender, race, and class inequalities in organizations via the institutional myths of meritocracy and efficiency as well as via institutional work that enables conditions for such reproduction (Amis et al., 2020; Bapuji, Ertug \& Shaw, 2020). Organizational studies need to address caste to create truly inclusive organizations in South Asia and beyond. And, as organizational scholars, we have a key role to play. If we don't attend to caste, we enable its reproduction. We disappear it and thus contribute to the normalization of the exploitation of people based on caste.

As researchers, we predominantly engage with problems in the formal sector and overlook the informal sector that accounts for nearly $95 \%$ of the working population in the Indian subcontinent, of which 93\% are lower castes (NCEUS, 2009). Put differently, we engage with the problems in urban offices, but ignore those who build the offices, i.e., millions of migrant labourers of all types of low castes. This is evidenced in the COVID-19 lockdowns in India, where thousands of migrant labourers had to walk hundreds of kilometres to return to their villages, with some succumbing to starvation and death en route. Further, we ignore the lower-caste contract workers who clean and maintain the swanky urban office spaces, particularly those who engage in sanitation and sewer cleaning, which other lower castes leave to Dalits (Varman \& Chakrabarti, 2004). In the lockdowns of COVID-19, it is these groups that have been most affected. But, would our future research questions cover them, or would they be limited, as important as these are, only to challenges of working from home, wellbeing of remote workers, and productivity differences by gender i.e., women with carer responsibilities, during the lockdown? (Bapuji et al., 2020a). In other words, caste challenges 
our understanding of where organizational studies problems are located. If we keep the aspirations, challenges, and voices of the lower castes out of our literature, we contribute to erasing their contributions and we normalize their exploitation.

Another important challenge that caste poses to researchers lies in their own positionality and its influence on the data collected and interpreted. For example, most researchers, including those with roots in the Indian subcontinent, tend to be less familiar with the nuances of caste. Therefore, it is important to understand and appreciate the challenges it entails, just as is the case with studying other marginalized groups. First, ethical sensitivities are involved in conducting research on caste, which may cause distress or unease for those who participate. Vulnerable participants like the lower castes are often apprehensive about sharing their experiences with outsiders; while some even question the 'privileged speaking for the marginalized'. Second, researchers may find it difficult to gain access to research sites. Organizations may be wary of granting access, because they may not 'explicitly' entertain caste in decisions, or it may be a sensitive topic. Finally, researchers may find it challenging to communicate the research on caste to an audience that is either not familiar with the context (i.e., researchers from outside the Indian subcontinent) or does not connect to caste, if not dismisses it altogether (i.e., most researchers with roots in the Indian subcontinent). As a result, it can be challenging to find the editors and reviewers who possess the familiarity and willingness to entertain research on caste.

Our role in society does not stop only at research and extends to education. We strive to make educational institutions a bedrock for multiple perspectives and an amalgam of novel outlooks. Similar to the normalization of hegemonies associated with white/male/upper class perspectives in curriculums, caste may also be reinforced through its normalization. Sensitizing business education to caste would mean paying attention to caste in the context of research and the case studies brought to the classroom. It would also mean improving caste diversity within 
academic departments, from the admission of students to faculty recruitment. If this is perceived as abnormal, it would be useful to question why caste diversity is problematic when gender, racial and ethnic diversity are not. It is through such representation that the de-caste'ing of our education becomes possible. In short, there is much to be done and much that organizational studies scholars can do within their own domain of influence to alleviate or at least stop reinforcing the existing inequalities of caste.

In conclusion, the caste system is neither archaic nor limited to the Indian subcontinent. Rather it is a thriving system of inequality around the world, yet it remains mostly invisible to organizations and organizational scholars. We call on organization scholars to focus on this system of inequality to address the challenges facing organizations and societies. Organizational scholars are in a good position to direct the attention of managers to the deleterious effects of the caste system on individuals and organizations, and in doing so, think about capitalism's reliance on inequality more broadly. However, we can do that only if we acknowledge the caste system and examine it in earnest.

\section{References}

Aldrich, D. P. (2010). Separate and Unequal: Post-Tsunami Aid distribution in southern India. Social Science Quarterly, 91(5), 1369-1389.

Amis, J. M., Mair, J., \& Munir, K. A. (2020). The organizational reproduction of inequality. Academy of Management Annals, 14(1), 195-230.

Andreescu, F. C. (2018). Opening up Bodies for Harvest: Embodiment and Global Capitalism. Theory \& Event, 21(2), 411-433.

Bataille, G. (1986). Erotism: Death and Sensuality. City Lights Books. 
Bapuji, H., \& Chrispal, S. (2020). Understanding economic inequality through the lens of caste. Journal of Business Ethics, 162 (3). 533-551.

Bapuji, H., Ertug, G., \& Shaw, J. D. (2020). Organizations and societal economic inequality: A review and way forward. Academy of Management Annals, 14(1):60-91.

Bapuji, H., Patel, C., Ertug, C., \& Allen, D. (2020a). Corona crisis and inequality: Why management research needs a societal turn. Journal of Management, 46(7):1205-22.

Bauman, Z. (2000) Liquid Modernity. Polity Press.

Bourdieu, P. (1998). Acts of resistance: Against the tyranny of the market (R. Nice, Trans.). Polity Press.

Butler, J. (2004). Precarious Life. The Power of Mourning and Violence. Verso.

Butler, J. (2009). Introduction: Precarious Life, Grievable Life. In Frames of War: When Is Life Grievable? Verso. 1-32.

Butler, J. (2015). Foreward. In Lorey I. (Ed.), State of insecurity: Government of the precarious (pp. vii-xi). Verso.

Caruana, R. Crane, A., Gold, S., \& LeBaron, G. (2020). Modern Slavery in Business: The Sad and Sorry State of a Non-Field, Business \& Society. doi: 10.1177/0007650320930417.

Chakravarti, U. (2012). Conceptualising Brahmanical patriarchy in early India: Gender, caste, class and state. Economic and Political Weekly, 28(14), 579-585.

Changoiwala, P. (2020, April 9). No Masks, No Gloves. Retrieved April 14, 2020, from https://foreignpolicy.com/2020/04/09/india-lockdown-sanitation-workers-manualscavengers-masks-gloves-coronavirus/

Chilisa, B. (2012). Postcolonial indigenous research paradigms. Indigenous research methodologies. Sage, 98-127.

Claus, L., \& Tracey, P. (2019). Making change from behind a mask: How organizations challenge guarded institutions by sparking grassroots activism. Academy of 
Management Journal, https://doi.org/10.5465/amj.2017.0507.

Côté, S. (2011). How social class shapes thoughts and actions in organizations. Research in Organizational Behavior, 31, 43-71.

Crane, A. (2013). Modern slavery as a management practice: Exploring the conditions and capabilities for human exploitation. Academy of Management Review, 38(1), 49-69.

Cruz, K., Davidson, J.O.C., Julia \& Sanchez Taylor, J.S. (2019). Tourism and sexual violence and exploitation in Jamaica: contesting the 'trafficking and modern slavery' frame. Journal of the British Academy, 7(s1):191-216.

Dandridge, T. C. (1986). Ceremony as an integration of work and play. Organization Studies, 7(2), 159-170.

Desai, S., \& Dubey, A. (2012). Caste in 21st Century India: Competing Narratives. Economic and Political Weekly, 46(11), 40-49.

Deshpande, M. S. (2010). History of the Indian Caste System and Its Impact on India Today. San Luis Obispo.

Dutt, Y. (2020, July 14). The Specter of Caste in Silicon Valley. The New York Times. Retrieved July 15, 2020, from https://www.nytimes.com/2020/07/14/opinion/castecisco-indian-americans-discrimination.html

George, G., Howard-Grenville, J., Joshi, A., \& Tihanyi, L. (2016). Understanding and tackling societal grand challenges through management research. Academy of Management Journal, 59(6), 1880-1895.

George, M. (2008). Religious patriarchy and the subjugation of women in India. International Journal of Interdisciplinary Social Sciences, 3(3), 21-30.

Gettleman, J., \& Raj, S. (2018, April 06). Lower-Caste Fury Shakes India, and Hints at Fiery Election Ahead. The New York Times. Retrieved March 15, 2019, from https://www.nytimes.com/2018/04/06/world/asia/india-dalit-protest.html 
Goffman, E. (1961). Asylums: Essays on the social situation of mental patients and other inmates. Penguin Books.

Green, C. (1993). Advanced Capitalist Hegemony and the Significance of Gramsci's Insights: A Restatement. Social and Economic Studies, 42(2-3), 175-207.

Grey, M. (2005). Dalit Women and the Struggle for Justice in a World of Global Capitalism. Feminist Theology, 14(1), 127-149.

Guru, G., \& Sarukkai, S. (2018). The cracked mirror: An Indian debate on experience and theory. Oxford University Press.

Heise, D., \& MacKinnon, N. (2010). Self, identity, and social institutions. Springer.

Hertz, R. (1973 [1909]). 'The pre-eminence of the right hand'. In: R. Needham(ed.). Right and left. University of Chicago Press.

Harvey, E. D. (Ed.). (2003). Sensible flesh: on touch in early modern culture. University of Pennsylvania Press.

Hudson, B. A., Okhuysen, G. A., \& Creed, W. D. (2015). Power and institutions: Stones in the road and some yellow bricks. Journal of Management Inquiry, 24(3), 233-238.

Jal, M. (2018). The Phenomenology of Silent Blindness: Understanding Caste in India, Part I. Critique, 46(2), 221-240.

Joshi, S., \& Malghan, D. (2018, January 18). Why are there still such few SCs, STs and OBCs at IIMs?. Retrieved August 4, 2020 from https://thewire.in/caste/iim-sc-st-obcdiversity

Kalleberg, A. L., \& Vallas, S. P. (2018). Probing precarious work: Theory, research, and politics. Research in the Sociology of Work, 31(1), 1-30.

Kalnins, A., \& Chung, W. (2006). Social capital, geography, and survival: Gujarati immigrant entrepreneurs in the US lodging industry. Management Science, 52(2), 233-247.

Kapur, D. (2010). Diaspora, development, and democracy: The domestic impact of 
international migration from India. Princeton University Press.

Kara, S. (2019). Tainted Garments. University of California, Berkeley.

Marx, K. (1967). Capital; a Critique of Political Economy. International Publishers

Leder, D. (1990). The absent body. London: University of Chicago Press.

Lee, R. L., \& Rajoo, R. (1987). Sanskritization and Indian ethnicity in Malaysia. Modern Asian Studies, 21(2), 389-415.

Leonard, K. I. (2005). South Asians in the Indian Ocean world: Language, policing, and gender practices in Kuwait and the United Arab Emirates. Comparative Studies of South Asia, Africa and the Middle East, 25(3), 677-686.

Lukes, S. (2005). Power: A radical view. Palgrave Macmillan

Mahadevan, J. (2015). Caste, purity, and female dress in IT India: embodied norm violation as reflexive ethnographic practice. Culture and Organization, 21(5), 366-385.

Mahalingam, R. (2007). Essentialism, power, and the representation of social categories: A folk sociology perspective. Human Development, 50(6), 300-319.

Mair, J., Wolf, M., \& Seelos, C. (2016). Scaffolding: A process of transforming patterns of inequality in small-scale societies. Academy of Management Journal, 59(6), 20212044.

Mandal, D. (2019, September 4). Why upper castes polish shoes or sweep roads when protesting quota for Dalits and OBCs. Retrieved May 1, 2020, from https://theprint.in/opinion/why-upper-castes-polish-shoes-or-sweep-roads-whenprotesting-quota-for-dalits-and-obcs/286243/

Martí, I., \& Fernández, P. (2013). The institutional work of oppression and resistance: Learning from the Holocaust. Organization Studies, 34(8), 1195-1223.

Marti, I., \& Mair, J. (2009). Bringing change into the lives of the poor: Entrepreneurship outside traditional boundaries. Institutional work: Actors and agency in institutional 
studies of organizations, 92-119.

McCarthy, L., \& Moon, J. (2018). Disrupting the gender institution: Consciousness-raising in the cocoa value chain. Organization Studies, 39(9), 1153-1177.

Metcalf, H., \& Rolfe, H. (2010). Caste discrimination and harassment in Great Britain. London: National Institute of Economic and Social Research.

NCEUS. (2009). The Challenge of Employment in India - An Informal Economy Perspective. Retrieved April 1, 2020, from: http://dcmsme.gov.in/The_Challenge_of_Employment_in_India_(Vol.\%20II).pdf

Parikh, P., Sute, S., \& Olwe, S. (2018, November 24). In Photos: Documenting Atrocities Against Dalits in Gujarat. Retrieved March 15, 2019, from https://thewire.in/caste/inphotos-documenting-atrocities-against-dalits-in-gujarat

Parrot, A., \& Cummings, N. (2008). Sexual enslavement of girls and women worldwide. Praeger Publishers

Pines, C. L. (1997). Ideology and false consciousness: Marx and his historical progenitors. SUNY Press.

Prakash, G. (1994). Subaltern studies as postcolonial criticism. The American historical review, 99(5), 1475-1490.

Prasad, A. (2012). Beyond analytical dichotomies. Human Relations, 65(5), 567-595.

Prasad, A., O’Brien, L.T., \& E. Smith Sockbeson, C. (2020). Caste at work: study of factors influencing attitudes toward affirmative action in India. Equality, Diversity and Inclusion, 39(6), 597-616.

Prasad, P., \& Prasad, A. (2000). Stretching the iron cage: The constitution and implications of routine workplace resistance. Organization Science, 11(4), 387-403.

Qureshi, I., Sutter, C., \& Bhatt, B. (2018). The transformative power of knowledge sharing in settings of poverty and social inequality. Organization Studies, 39(11), 1575-1599. 
Roberts, A. \& Zietsma, C. (2018). Working for an App: Organizational Boundaries, Roles and Meaning of Work in the "On-Demand" Economy. In: L. Ringel, P. Hiller, \& C. Zietsma (Eds.). Toward permeable boundaries of organizations? (Research in the Sociology of Organizations), 57, 195-225. Emerald Publishing.

Roopnarine, L. (2003). East Indian indentured emigration to the Caribbean: Beyond the push and pull model. Caribbean studies, 97-134.

Russell, A. M. (2017). Embodying the sacred: Understanding responses to human trafficking. In Foundations and Futures in the Sociology of Religion, 165-181. Routledge.

Saracini, N., \& Shanmugavelan, M. (2019). Caste and Development. London: Bond.

Sarukkai, S. (2009). Phenomenology of Untouchability. Economic and Political Weekly, 44(37), 39-48.

Siddique, Z. (2011). Evidence on caste based discrimination. Labour Economics, 18, S146S159.

Shields, C. (2016). Aristotle: De Anima. Oxford University Press.

Spivak, G. C. (1988). Can the subaltern speak?. In: Morris, R. (ed.) Can the subaltern speak? Reflections on the history of an idea, 21-78. Columbia University Press.

Srinivas, N. (2013). Could a subaltern manage? Identity work and habitus in a colonial workplace. Organization Studies, 34(11), 1655-1674.

Stryker, S., \& Serpe, R. T. (1994). Identity salience and psychological centrality: Equivalent, overlapping, or complementary concepts?. Social psychology quarterly, 16-35.

Tetlock, P. E., Kristel, O. V., Elson, S. B., Green, M. C., \& Lerner, J. S. (2000). The psychology of the unthinkable: taboo trade-offs, forbidden base rates, and heretical counterfactuals. Journal of personality and social psychology, 78(5), 853.

Tetlock, P. E. (2003). Thinking the unthinkable: Sacred values and taboo cognitions. Trends in cognitive sciences, 7(7), 320-324. 
Thomas, R. (2020). Brahmins as scientists and science as Brahmins' calling: Caste in an Indian scientific research institute. Public Understanding of Science, 0963662520903690.

Thomas, R. \& Geraci, R. (2018). Religious rites and scientific communities: Ayudha Puja as 'culture' at the Indian Institute of Science. Zygon: Journal of Religion and Science, 53(1).

Thorat, S., Banerjee, A., Mishra, V. K., \& Rizvi, F. (2015). Urban Rental Housing Market. Economic and Political Weekly, 27, 47-53.

Thorat, A. \& Joshi, O., (2015). The continuing practice of untouchability in India: Patterns and mitigating influences. India Human Development Study Working Paper, 2. Available at https://ihds.umd.edu/sites/ihds.umd.edu/files/publications/papers/ThoratJoshi3.pdf.

Toubiana, M. (2019). Once in orange always in orange? Identity paralysis and the enduring influence of institutions on identity.Academy of Management Journal. https://doi.org/10.5465/amj.2017.0826.

Varman, R., \& Chakrabarti, M. (2004). Contradictions of democracy in a workers' cooperative. Organization Studies, 25(2), 183-208.

Wiegman, R. (1995). American anatomies: Theorizing race and gender. Duke University Press.

World Bank. (2019). Poverty \& Equity Data Portal. Retrieved February 27, 2019, from http://povertydata.worldbank.org/poverty/country/IND

UNDP. 2019. Multidimensional Poverty Index 2019: Illuminating Inequalities. Retrieved April 17, 2020, from http://hdr.undp.org/en/2019-MPI.

Zwick-Maitreyi, M., Soundararajan, T., Dar, N., Bheel, R.F., and Balakrishnan, P. (2018) Caste in the United States. A Survey of Caste among South Asian Americans. Equality Labs, USA. 


\section{Author biographies}

Snehanjali Chrispal is a PhD Candidate in the Department of Management and Marketing, Faculty of Business and Economics, The University of Melbourne, Australia. Her research interests include institutions, focused on institutional work and emotions, and inequality, focused on gender and caste. Her work has been published in Journal of Business Ethics and The Routledge Companion to Anthropology and Business.

Hari Bapuji is Professor of Strategic Management and International Business at The University of Melbourne, Australia. His research interests lie at the intersection of business and society, with a recent focus on how economic inequality affects businesses, and vice versa. His research appeared in leading management journals (e.g., Academy of Management Annals, Journal of International Business Studies, Journal of Management, Journal of Management Studies, and Journal of Operations Management), and has also been noted for its impact on practice and policy.

Charlene Zietsma is Associate Professor at the Smeal College of Business, Pennsylvania State University. She studies institutional work, institutional change processes, social and sustainable entrepreneurship and social emotions, usually in the context of social and ecological issues and social movements. Her work has been published in Administrative Science Quarterly, Academy of Management Journal, Academy of Management Review, Organization Science, Organization Studies, Journal of Business Venturing and others. 


\section{University Library}

\section{- M M I E E R VA A gateway to Melbourne's research publications}

Minerva Access is the Institutional Repository of The University of Melbourne

Author/s:

Chrispal, S;Bapuji, H;Zietsma, C

Title:

Caste and Organization Studies: Our Silence Makes Us Complicit

Date:

2020-10-04

Citation:

Chrispal, S., Bapuji, H. \& Zietsma, C. (2020). Caste and Organization Studies: Our Silence Makes Us Complicit. ORGANIZATION STUDIES, 42 (9), pp.1501-1515. https:// doi.org/10.1177/0170840620964038.

Persistent Link:

http://hdl.handle.net/11343/247800 